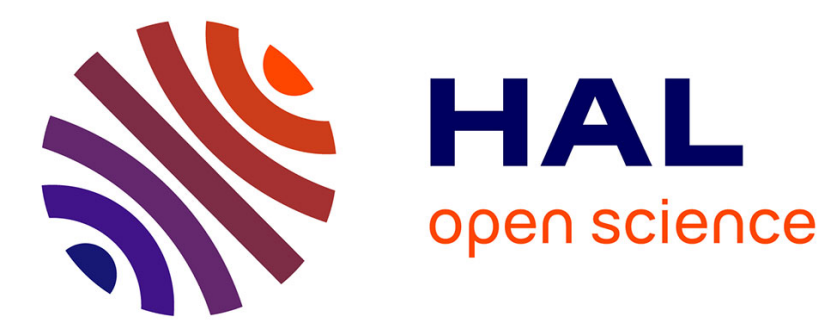

\title{
A women's boom in the boardroom: effects on performance?
}

\author{
Mareva Sabatier
}

\section{To cite this version:}

Mareva Sabatier. A women's boom in the boardroom: effects on performance?. Advances in Applied Microeconomics, 2015, 47 (26), pp.2717-2727. 10.1080/00036846.2015.1008774 . hal-01158917

\section{HAL Id: hal-01158917 https://hal.univ-grenoble-alpes.fr/hal-01158917}

Submitted on 2 Jun 2015

HAL is a multi-disciplinary open access archive for the deposit and dissemination of scientific research documents, whether they are published or not. The documents may come from teaching and research institutions in France or abroad, or from public or private research centers.
L'archive ouverte pluridisciplinaire HAL, est destinée au dépôt et à la diffusion de documents scientifiques de niveau recherche, publiés ou non, émanant des établissements d'enseignement et de recherche français ou étrangers, des laboratoires publics ou privés. 


\title{
A Women's Boom in the Boardroom: Effects on Performance?
}

\author{
Mareva Sabatier \\ IREGE - Université Savoie Mont-Blanc \\ BP80439, 749444 Annecy-le-Vieux Cedex, France \\ E.mail: mareva.sabatier@univ-savoie.fr
}

This article analyzes whether improving gender diversity in boardrooms improves firms' economic performance. In the context of French CAC40-listed companies between 2008 and 2012, this research uses instrumental variable panel regressions, including production frontier estimates, to arrive at two key results. First, gender diversity in boards depends on firms' attributes, including their previous gender promotion strategies. Second, promoting women in boardrooms has a significant and positive effect on economic performance, after accounting for the endogeneity of diversity. Gender diversity even reduces corporate inefficiencies and enables firms to come closer to their optimal performance. 


\section{I- Introduction}

Whereas women account for $56 \%$ of the workforce in Europe, they held only $11 \%$ of boardroom seats in large companies in 2013. Furthermore, they represent $45 \%$ of university graduates but only $14 \%$ of the directors of boards in large firms. These statistics highlight the continued existence of a glass ceiling and the persistent challenges women face in accessing the highest positions in organizations. In France, the situation appears slightly better; the percentage of female directors of boards reached 28\% in 2013 among the 40 larger listed companies (CAC40), reflecting a 20 percentage point increase over the past six years. This boom is largely a result of the 2011 passage of the Copé-Zimmermann Act, which introduced a gender quota policy similar to Norway's that requires the boards of large French companies to feature at least $40 \%$ women by 2017 .

This quota, designed to promote parity, was motivated by not just ethical and social responsibility reasons but also economic rationales. Because boards appoint and monitor CEOs and guide the firm's strategy (Bagliono and Colombo, 2013 ; Adams et al., 2010), boardroom composition has a strong impact on firm performance (Hermalin and Weisbach, 2003). For example, the share of insiders, defined as people who work for the firm or are closely related to it (Agrawal and Knoeber, 1999), and board size (Kini et al., 1995) tend to hinder performance. In addition, directors' own attributes, such as skills, networks, or experience, greatly influence firm performance (Terjesen et al., 2009). In their study of U.S. companies, Erhardt et al. (2003), assert that diversity on boards, in terms of gender and ethnicity, affects economic performance too. 
With this study, we focus on gender diversity and consider several explanations for its strong influence, related to the distinct attributes exhibited by female and male directors. Female directors on average are more educated and attend different schools than their male peers (Singh et al., 2008). Female administrators also are younger (Ross-Smith and Bridge, 2008; Sealy et al., 2007) and have more international experience but less executive experience before their appointment (Zelechowski and Bilimoria, 2004). They come from the private sector but, unlike male directors, also may have worked in nonprofit organizations or the public sector, such as universities or research departments (Sealy et al., 2007; Singh et al., 2008). Finally, male directors' attributes tend to be similar to those of existing CEOs, in terms of their educational and professional paths, such that male directors gain close proximity to insiders. Female directors instead take the role of outsiders, with greater independence from CEOs (Peterson and Philpot, 2007), and they thus may be better able to monitor CEOs, with notable influences on company performance.

Because female directors have different educational and professional paths than male directors, their human capital endowments also differ (Becker, 1964), which enables them to provide more external expertise (Hillman et al., 2000, 2007). With regard to their attitudes, women tend to be more sensitive to risk and more likely to adopt long-term strategies than are men (Byrnes et al., 1999; Eckel and Grossman, 2002, 2008). They generally are better prepared for meetings (Huse and Solberg, 2006) and ask more questions than male directors (Konrad et al., 2008). Adams and Ferreira (2009) find that gender diversity on boards increases global directors' attendance and the probability of CEO turnover in response to poor economic results. 
Accordingly, low gender diversity could deprive boards of the skills and resources held by female directors, potentially leading to suboptimal decisions and economic underperformance. Alternatively, quota policies that modify the functioning of boards and corporate governance could jeopardize the delicate balance among stakeholders in firms (Adams and Ferreira, 2009). Thus, despite substantial empirical literature devoted to this topic, no consensus has emerged. For example, Carter et al. (2003) study Fortune 100 companies and find a positive effect of the presence of women on boards on performance. This result is confirmed in US Community Developpment Loan Funds (Hartarska and Nadolnyak, 2012). But other studies indicate no significant effect (e.g., U.S. data, Carter et al., 2010; Danish data, Rose, 2007; Fortune 500, Farrell and Hersch, 2005). Still others reveal a negative impact (Swedish data, Daunfeldt and Rudholm, 2012; U.S. data, Adams and Ferreira, 2009; Norwegian data, Ahren and Dittmar, 2012).

This lack of consensus appears mainly due to three challenges to statistical evaluations of the impact of gender diversity on performance. First, companies operate in very different institutional (regulatory and legislative) contexts, which prevents researchers from establishing a homogenous effect of diversity. Adams and Ferreira (2009) even argue that the impact of gender diversity on performance depends on the type of governance: In high governance settings, greater gender diversity leads to counterproductive overmonitoring of CEOs. Second, the promotion of women can produce a positive effect only if some minimum number is reached (Kanter, 1977). Below this threshold (estimated at three women), tokenism effects likely predominate, such that sole female directors are not sufficiently influential to 
alter decisions. Third, diversity in boards is probably not an exogenous variable but instead reflects the firm's attributes, in particular the ownership structure (Miller and Le Breton-Miller, 2006), and the firm's strategy (Adams et al., 2010; Demsetz and Lehn, 1985; Hillman et al., 2007; Moulin and Point, 2012), and that firm's characteristics and strategy themself influence performance. It is thus difficult to establish whether strategy, defined ex ante, or its resulting gender diversity actually influences performance.

In France, despite the strong impacts of the Copé-Zimmermann Act, studies of the outcomes of the increased gender diversity in boards remain scarce (LandrieuxKartochian, 2004; Saint-Onge and Magnan, 2013) and mostly restricted to statistical observations of parity on boards or top management. Two exceptions are notable. First, Ferrary $(2009,2010)$ examines the effect of top management gender diversity on the performance of CAC40 companies and concludes that not only do the most diverse companies exhibit better average performance, but they were much more resilient to the subprime crisis. Second, Moulin and Point (2012) analyze the determinants of gender diversity on the boards of companies listed in the SBF120 in 2008. It depends on various firm characteristics, but particularly the shareholding structure. These findings refute the notion that gender diversity is a random phenomenon. Yet neither of these important studies seeks to measure directly the performance implications of gender diversity in boardrooms. They also pertain to the period before passage of the Copé-Zimmermann Act. Therefore, we lack studies that explicate the effect of the women's boardroom boom on performance. 
To fill this gap and measure the effect of gender diversity in large companies on their performance, we construct an original database, compiled from the annual activity reports of listed CAC40 companies in 2012, for a five-year period (2008-2012). With these activity reports, we can identify, for each firm and each year, its economic performance, boardroom composition, and several other characteristics (e.g., size, industry). The database is thus a balanced panel of 200 observations. To quantify the impact of boards' gender diversity on performance, we estimate instrumental variable panel regressions, while accounting for the endogeneity of boards' gender diversity. We complete these regressions with frontier estimates so that we can test whether improving gender diversity can help firms reach their optimal performance, that is, the performance they should attain if they optimally exploit their inputs, relative to others. With this econometric strategy, we can establish a global effect of gender diversity on performance, as well as quantify how much this diversity might limit corporate inefficiencies.

The structure of our article is as follows: We present our data and basic statistics about female representation on corporate boardrooms, along with our methodological strategy, in Section 2. In Section 3, we analyze the relation between diversity and performance. Section 4 concludes. 


\section{II- Data and methodology}

Data

Our sample consists of a balanced panel of French companies, listed in the CAC40 index in 2012. For each firm, we collected annual activity reports between 2008 and 2012 and thus gathered rich information about the firms' characteristics (business segment, size, shareholding structure), performance, and boardroom composition. This sample comprises 200 firms, with 2,825 directors.

We use three performance measures: return on equity (ROE), equal to the ratio of net income to shareholder equity; return on assets (ROA), or the ratio of net income to the book value of assets; and a proxy of Tobin's $q$, which uses the ratio of the firm's market value to its book value. Unlike the first two measures, the Tobin's $q$ focuses on expectations of future performance (Demsetz and Villalonga, 2001), so a Tobin's $q$ ratio greater than 1 indicates the firm can create more value by using its available resources effectively.

For the boardrooms, we calculate the percentage of female directors in each firm each year. We also observe if male directors are connected to female directors in other boardrooms and calculate, for each firm, the average ratio of women in connected boardrooms. This variable instruments for the fraction of female directors, because we suspect that when men are more connected to female directors, they are better able to promote gender diversity (Adams and Ferreira, 2009). To take into account potential recurrence effect in the choice of directors, we also introduce a past indicator about the percentage of female directors on boards before the CopéZimmerman reform. But, as past indicators can inform on firms' preference for 
gender diversity, their inclusion as instruments could cause bias dude to timeinvariant unobserved heterogeneity. To overcome this problem, we choose to introduce not the past fraction of women but the variation in the pre-reform fraction of women on boards, as suggested by Ahern and Dittmar (2012). We provide these summary statistics in Table 1.

Table 1. Summary statistics

\begin{tabular}{|c|c|c|c|c|}
\hline Variables & Mean & S.D. & Minimum & Maximum \\
\hline \multicolumn{5}{|l|}{ Board characteristics } \\
\hline Number of directors in boards & 14.13 & 3.24 & 8 & 24 \\
\hline Female directors fraction & 0.16 & 0.12 & 0 & 0.62 \\
\hline $\begin{array}{l}\text { Female directors fraction in connected } \\
\text { boardrooms }\end{array}$ & 0.15 & 0.11 & 0 & 0.66 \\
\hline $\begin{array}{l}\text { Variation in the pre-reform fraction of } \\
\text { women }(2003-2008)\end{array}$ & 0.04 & 0.06 & $-0,04$ & 0.25 \\
\hline \multicolumn{5}{|l|}{ Performance } \\
\hline Tobin's q & -0.43 & 0.61 & -3.09 & 0.87 \\
\hline$R O A$ & 3.65 & 4.49 & -10.49 & 41.48 \\
\hline$R O E$ & 13.43 & 11.53 & -32.57 & 51.33 \\
\hline \multicolumn{5}{|l|}{ Firm characteristics } \\
\hline Size (number of employees) & 106355.5 & 83220.02 & 1464 & 475976 \\
\hline Date of creation & 1941 & 64 & 1665 & 2011 \\
\hline Independence proxy & 0.68 & 0.47 & 0 & 1 \\
\hline Family-controlled firm & 0.25 & 0.43 & 0 & 1 \\
\hline Business sector (service) & 0.33 & 0.47 & 0 & 1 \\
\hline
\end{tabular}

Notes: The independence proxy is a binary variable, equal to 1 if no shareholder holds more than $25 \%$ of the total shares of the company.

Between 2008 and 2012, the female director fraction was $16 \%$ on average, though this mean value hides an extremely large increase, in that the percentage of female directors on boards increased from $10 \%$ in 2008 to nearly $27 \%$ in 2012 , a 2.7 -fold increase in just five years (see Figure 1). This clear boom of women in boardrooms mainly arose between 2010 and 2011, following passage of the Copé-Zimmermann 
Act. The percentage of women on boards doubled over these two years. Moreover, over $80 \%$ of firms have surpassed the threshold of three women in their boards, which should enable gender diversity to produce positive effects (see Figure 2).

Figure 1. Rate of female directors on boards

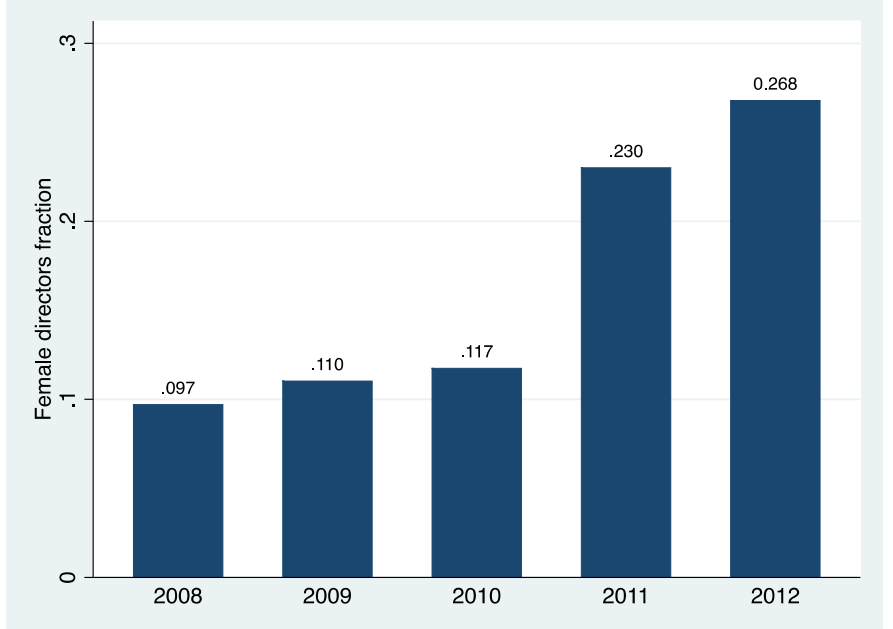

Figure 2. Percentage of firms with at least three women on their boards

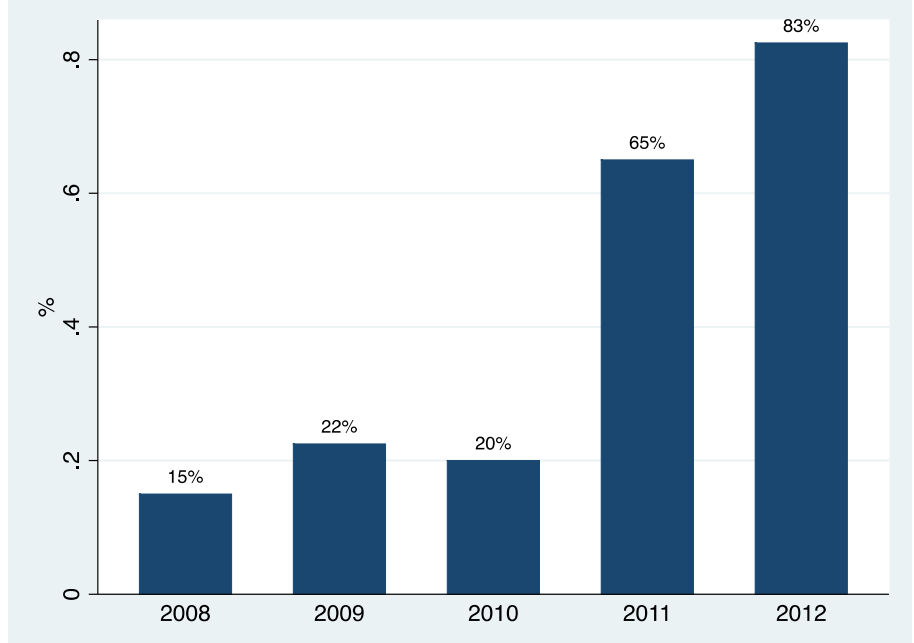

To explore the potential statistical link between gender diversity and performance, we compared the performance achieved by two types of companies: those for which the percentage of female directors was below the sample median (low gender diversity) and those with percentages above the median (high gender diversity). As the results in Table 2 indicate, average performance is greater in companies with 
high gender diversity on two performance indicators: ROE and Tobin's $q$. We found no statistical difference in ROA.

Table 2. Average economic performance and gender diversity

\begin{tabular}{|l|l|l|l|}
\hline \multirow{2}{*}{} & \multicolumn{3}{|l|}{ Performance Measure } \\
\cline { 2 - 4 } & ROE & ROA & Tobin's q \\
\hline Low diversity & 12.65 & 3.67 & 0.66 \\
\hline High diversity & 14.09 & 3.64 & 0.87 \\
\hline Total & 13.43 & 3.66 & 0.77 \\
\hline
\end{tabular}

Our data also highlight links between gender diversity and firms' characteristics (see Table 3), such that companies with the most diverse boards (third and fourth quartiles for the gender diversity variable) seem more independent, more familycontrolled, older, and better positioned in the service sector. We find dynamics in gender diversity processes, because the proportion of female directors was, on average, greater on boards that promote more women ex ante. Finally, when board members previously were connected to more women on other boards, gender diversity was greater, suggesting that directors are sensitive to the gender diversity of other boards.

Table 3. Gender diversity and firm attributes

\begin{tabular}{|c|c|c|c|c|c|}
\hline & \multicolumn{4}{|c|}{ Fraction of Female Directors } & \multirow{2}{*}{ Total } \\
\hline & First quartile & Second quartile & Third quartile & Fourth quartile & \\
\hline \multicolumn{6}{|l|}{ Firms' attributes } \\
\hline Independent firm & 0.67 & 0.53 & 0.73 & 0.74 & 0.68 \\
\hline Family-controlled firm & 0.18 & 0.30 & 0.21 & 0.30 & 0.25 \\
\hline Size & 115534.60 & 113230.60 & 103680.50 & 95067.28 & 106355.50 \\
\hline Date of creation & 1948.90 & 1952.58 & 1935.49 & 1929.26 & 1940.80 \\
\hline Business segment: services & 0.16 & 0.35 & 0.35 & 0.43 & 0.33 \\
\hline \multicolumn{6}{|l|}{ Instruments } \\
\hline $\begin{array}{r}\text { Female directors fraction in } \\
\text { connected boardrooms }\end{array}$ & 0.08 & 0.12 & 0.16 & 0.24 & 0.15 \\
\hline $\begin{array}{r}\text { Variation in the pre-reform fraction } \\
\text { of women }(2003-2008)\end{array}$ & 0.02 & 0.04 & 0.05 & 0.06 & 0.04 \\
\hline
\end{tabular}


The descriptive statistics thus show a link between the percentage of female directors on boards and performance indicators, as well as a relationship between gender diversity and firms' attributes, which also could affect performance. To establish causal links across these variables, we undertake econometric analyses.

\section{Methodology}

Following previous empirical literature (e.g., Campbell and Minguez-Vera, 2008), we estimate a performance equation using a panel model. We test two specifications: a random-effect model and a fixed effect model. The fixed effect model can control for any observed and unobserved firm characteristics that are constant over time and that may influence the firm's performance. To choose between the two models, we perform a Hausman test (Hausman and Taylor, 1981). Moreover, to estimate the effect of gender diversity in boards on performance, we also must control for an endogeneity bias (Adams and Ferreira, 2009). This bias is likely in our study, because the descriptive statistics revealed links between the percentage of female directors and firms' characteristics. Thus, unobserved variables, such as preferences about gender diversity or the corporate culture, likely affect both gender diversity and performance. When such a bias exists, an instrumental variables estimation procedure is required (Baltagi, 2013). This procedure consists of estimating the performance equation while correcting for the endogeneity of the rate of female directors on boards. We therefore use two instruments to explain the gender diversity variable: the fraction of female directors in connected boards, as recommended by Adams and Ferreira (2009), and the variation in the pre-reform fraction of women on each board, to account for temporal recurrence effects in gender diversity 
strategies (Ahern and Dittmar, 2012). We perform a Hansen-Sargan overidentification test (Davidson and MacKinnon, 2004; Baum et al., 2003) to test the null hypothesis that the excluded instruments are valid instruments, i.e., uncorrelated with the error term and correctly excluded from the estimated equation.

We perform these estimates with a frontier model, so that we can determine if gender diversity partly explains corporate inefficiencies in terms of economic performance. These inefficiencies reflect the difference between the performance achieved (i.e., output) and the means companies use to achieve this performance (i.e., inputs), as defined by Farrell (1957). If firms perfectly use their inputs, relative to other, equivalent firms, their relative performance is optimal, because it would not be possible for them to achieve better performance with the resources they deploy. In this optimal scenario, firms reach their production frontier. However, if firms do not fully exploit their inputs, their relative performance is lower than the performance they could achieve in an optimal situation. The difference between actual and optimal performance reveals the technical inefficiency, that is, the potential scope for improved performance if the inputs were used more effectively.

Formally, we can estimate the frontier and inefficiency terms with a stochastic frontier method (Battese and Coelli, 1995; Belotti et al., 2012) and the following equation:

$$
\operatorname{perf}_{i t}=a+b^{\prime} X_{i t}+\varepsilon_{i t},
$$

where perf indicates the performance of firm $i$ at time $t ; X$ is the vector of inputs (e.g., size, business segments); and $\varepsilon$ regroups the unobserved terms $e_{i t}$, and inefficiency parameters ine $f f_{i}$, as: 


$$
\varepsilon_{i t}=e_{i t}-i n e f f_{i}
$$

Following Kumbhakar et al. (1991) and Huang and Liu (1994), we test whether the inefficiency parameters, ine $f f_{i}$, depend on observed factors, and gender diversity in particular; we define these parameters as:

$$
\text { ineff } f_{i} \rightarrow \mathrm{N}^{+}\left(\mu_{i}, \sigma_{\text {ineff }}^{2}\right) \text {, with } \mu_{i}=\exp \left(\gamma^{\prime} z_{i}\right)
$$

where $z_{i}$ contains a constant and the gender diversity variable.

Because the percentage of female directors may depend on specific characteristics (and thus be endogenous), we adopt a two-step method. First, we consider the percentage of women, given the characteristics of the company, the proportion of female directors in the previous year, and the percentage of women in connected boards. Second, we estimate the effect of the predicted ratio of women on boards (from the first step) on the inefficiency parameters. Thus we are sure to measure the real impact of gender diversity on performance ${ }^{1}$.

\section{III- Results and discussion}

Table 4 presents the results for the ROE performance indicator; the parallel results for ROA and Tobin's $\mathrm{q}$ are in the appendix, because we find no significant differences in the results across these performance indicators.

First, let us comment the robustness of our estimates. Our panel estimates give very close results about the impact of the women fraction on boards on firm's

\footnotetext{
${ }^{1}$ Note that we estimate separate regressions for the 2008-2010 period, that is before the women boom on boards and afterwards. Results do not vary accross the periods.
} 
performance. But, the Hausman test leads us to prefer the random effect panel model to the fixed effect one. Time-invariant covariates (economic sector, independency proxy, business segments) included in the random effect model seem thus to sufficient to capture firms' heterogeneity. Moreover, the Hansen-Sargan test calls for a validity of our instruments, which are not correlated with errors terms. Finally, our estimates can be qualified as robust.

Across variables, we note that gender diversity is not an exogenous variable; it depends strongly on firm attributes. In our data, business segments, size, and the ownership structure (related to the degree of independence or a family ownership) have no impact on gender diversity, in contrast with prior studies (e.g., Moulin and Point, 2012 or Miller and Le Breton-Miller, 2006). Nor does past firm performance influence gender diversity. Contrary to Farrell and Hersch's (2013) findings among Fortune 500 companies before the 2000 s, we find that the most efficient firms do not necessarily have more diversity on their boards. Finally, similar to Daunfledt and Rudholm (2012), we highlight a one-way effect from gender diversity to performance, not a simultaneous effect. 
Table 4. Determinants of gender diversity on boards

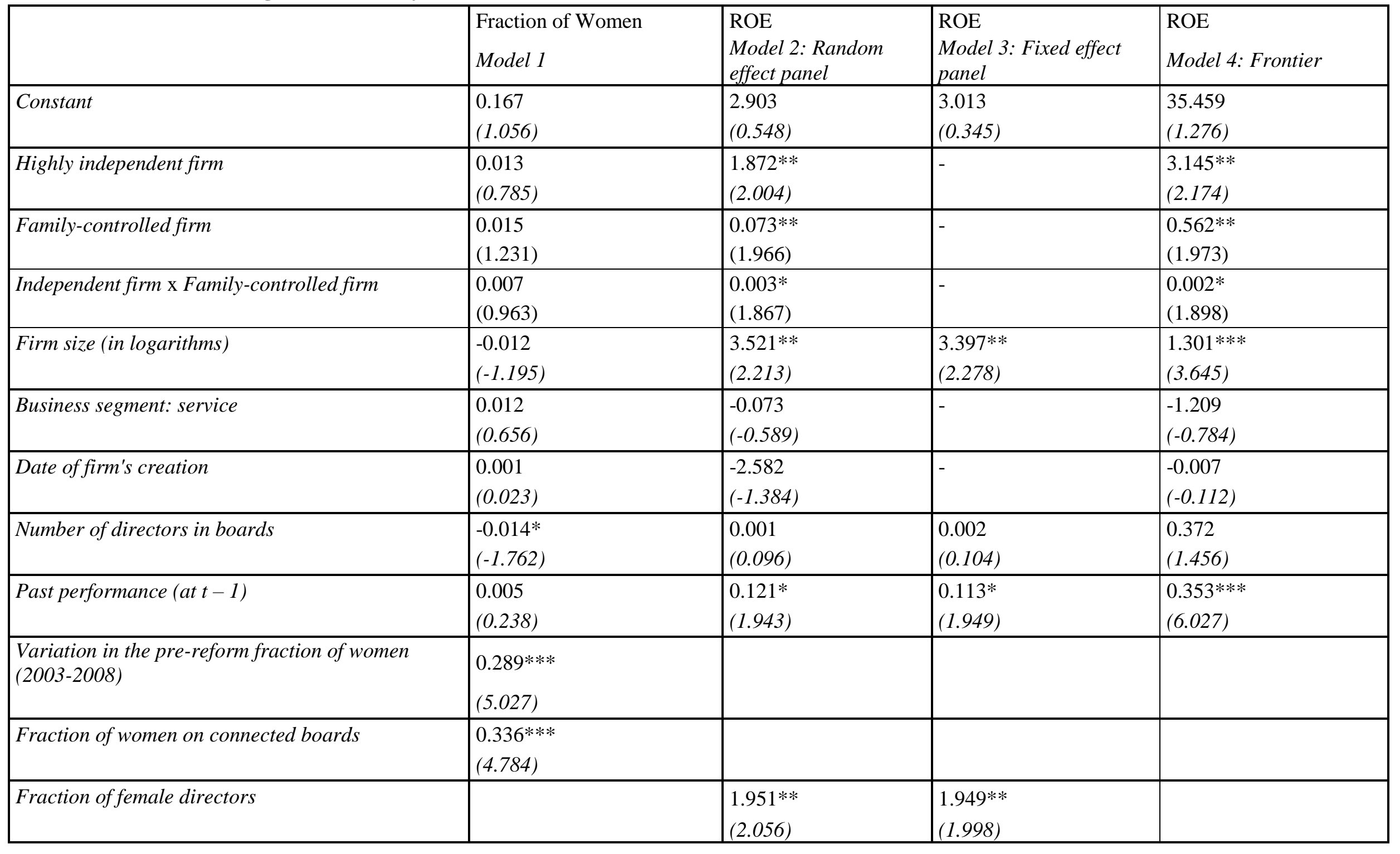




\begin{tabular}{|c|c|c|c|c|}
\hline$M u$ & & & & $\begin{array}{l}16.457 * * * \\
(14.126)\end{array}$ \\
\hline Vsigma & & & & $\begin{array}{l}-10.562 \\
(-0.870)\end{array}$ \\
\hline \multicolumn{5}{|l|}{ Inefficiency terms } \\
\hline Estimated fraction of women on boards (Model 1) & & & & $\begin{array}{l}-0.755^{* * *} \\
(-2.495)\end{array}$ \\
\hline $\mathrm{R} 2$ (total) & 0.612 & 0.523 & 0.519 & \\
\hline Log of likelihood & & & & -559.034 \\
\hline Hausman test value (FE model vs. RE model) & & \multicolumn{2}{|l|}{2.084} & \\
\hline Number of firms & 40 & 40 & 40 & 40 \\
\hline
\end{tabular}

Notes: Student's $t$ values appear in brackets.

$* * *$ Significant at $1 \%$.**Significant at $5 \%$. $*$ Significant at $10 \%$. 
In contrast, boards' attributes strongly explain gender diversity. The number of directors exerts a negative effect on diversity, which may be because in our data, the largest boards are characterized by more multiple directorships, which is a practice more common among men than women. We thus posit that French companies might face difficulties in recruiting directors. Limiting board sizes would facilitate directors' cooptation, especially for women. Furthermore, we note strong temporal recurrence effects in gender diversity that have been neglected in previous literature. The more diverse boards have been in the past (higher variation in the pre-reform fraction of women on boards), the more diverse they are in the future. This benefit may stem from learning effects related to the recruitment and appointment of female directors, or else reflect network and reputational effects. Similar to Adams and Ferreira (2009), we find that when male directors are connected to gender-diverse other boards, the percentage of female directors in the focal board is higher. Male directors thus seems more likely to recruit female directors when they participate in other diverse boards or when their network includes more women, either because they are more familiar with diversity or are better able to assess women's distinct skills (Carli, 2000). In turn, they function well as prescribers of gender diversity.

The women's boardroom boom observed during 2008-2012 contributed to better firm performance, all else being equal. This result is in line with Ferrary's (2010) conclusion of a positive performance effect of gender diversity in top management. Our data do not indicate a strong risk of tokenism though (Kanter, 1977), in that most observed companies already have exceeded the critical threshold of three female directors. Gender diversity, invoked mainly by the Copé-Zimmermann Act, 
thus has positive results in terms of better representation of women and from an economic perspective.

According to our frontier estimates, accelerating gender diversity on boards would reduce corporate inefficiency and allow companies to approach their optimal performance level. The firms in our sample achieved, at best, only $83 \%$ of their optimal performance (Table 5). As our results highlight, to reduce corporate inefficiencies, companies should increase the gender diversity of their boards, because the female director ratio has a significant, negative effect on inefficiency. In Table 4 (Model 4), a 10-percentage point increase in the number of women on boards reduces inefficiencies by about seven points, bringing firms in closer proximity to their optimal performance.

\section{Table 5. Corporate inefficiency terms}

\begin{tabular}{|l|l|l|l|l|}
\hline & Mean & St. Dev. & Minimum & Maximum \\
\hline ROE & 17.034 & 8.756 & 0.015 & 55.867 \\
\hline ROA & 21.115 & 7.082 & 0.043 & 47.045 \\
\hline Tobin's $q$ & 19.689 & 6.059 & 0.004 & 50.139 \\
\hline
\end{tabular}

From the $26.6 \%$ average percentage of women on boards in 2012, an increase of 10 percentage points would imply compliance with the quota imposed by the CopéZimmermann Act but also help firms achieve $90 \%$ of their performance potential. Our analysis thus emphasizes the economic benefits for CAC40-listed companies that promote more women to boards. However, our quantitative analysis cannot specify which mechanism underlies this positive impact. Prior literature offers some ideas. For example, the effect could result from the more efficient, stronger control exerted by more diverse boards, which tend to exhibit more independence from 
CEOs (Carter et al., 2003). In contrast with some predicted fears (e.g., Adams and Ferreira, 2009), the women's boom in boardrooms has not led to overmonitoring. In addition, gender diversity might introduce new skills to boards (Hillman et al., 2000), which could improve their effective decision making or enhance their risk considerations.

\section{IV- Conclusion}

A real women's boom has been observed in French corporate boards following the passage of the Copé-Zimmermann Act in 2011. Anticipating the $40 \%$ quota for female directors by 2017, large companies have begun recruiting more women, such that the percentage of women on boards has increased by about 20 points in six years, to reach $28 \%$ in 2013 . The impact of this shift on firm performance has not been studied previously, and the lack of consensus in research predictions offers no insights into its effects.

We have sought to fill this gap by analyzing companies listed in CAC40 in 2012, over a five-year period (2008-2012). The original (balanced panel) database enables us to observe economic performance indicators, the percentage of women on boards, and other key business attributes (e.g., independence indicator, size, industry). Using an instrumental panel model and a frontier model, we thus uncovered three notable results. First, gender diversity is strongly influenced by firm characteristics, including previous gender diversity and gender diversity in connected boards. Recruiting female directors is not a random process but rather a result of a corporate strategy, implemented over the long run. Second, when we account for the endogeneity of gender diversity in boards, we find a significant and positive effect on 
performance. Companies whose boards are more diverse in terms of gender achieve higher performance indicators, all else being equal. Third, by promoting gender diversity, firms can approach their optimal performance level, defined as the performance that they should achieve, were they to exploit their inputs perfectly.

From a public policy point of view, our results indicate that introducing quotas for women's representation on boards has prompted French companies to recruit more female directors. This of course needs to be studied in a more extended period to take into account potential long-term effects. But, this gender diversity in turn has short term positive effects for corporate social responsibility and diversity goals, as well as for economic performance. To encourage further gender diversity, several additional motivators are available. For example, smaller boards are preferable to avoid multiple directorships, which is a practice mainly adopted by men. Firms should appoint male directors who already are linked with female directors on other boards, because these more diverse networks facilitate the recruitment of female directors. Finally, current gender diversity efforts have positive long-term effects on the future recruitment of female directors. Companies therefore should regard the integration of women into their boards as investments that produce positive effects in both the short and the long term.

\section{References}

Adams R., Ferreira D. (2009) Women in Boardroom and Their Impact on Governance and Performance, Journal of Financial Economics, 94, 294-309.

Adams R., Hermalin B., Weisbach M. (2010) The Role of Boards of Directors in Corporate Governance: A Conceptual Framework and Survey, Journal of Economic Literature, 48, 1, 58-107.

Agrawal A., Knoeber C.R. (1996) Firm Performance and Mechanisms to Control Agency Problems between Managers and Shareholders, Journal of Financial and Quantitative Analysis, 31, 3, 337-397. 
Ahren K.R., Dittmar A. (2012) The Changing of the Boards: The Impact on Firm Valuation of Mandated Female Board Representation, Quarterly Journal of Economics, 127, 137-197.

Baglioni A., Colombo L. (2013) The Efficiency View of Corporate Boards: Theory and Evidence, Applied Economics, 45, 497-510.

Baltagi B.H. (2013) Econometric Analysis of Panel Data, 5th ed., Chichester, UK, Wiley.

Battese G.E., Coelli T.J. (1995) A Model for Technical Inefficiency Effects in a Stochastic Frontier Production Function for Panel Data, Empirical Economics, 20, 325-332.

Baum C.F., Schaffer M.E., Stillman S. (2003) Instrumental Variables and GMM: Estimation and Testing, Stata Journal, 3, 1-31.

Becker G. (1964) Human Capital, University of Chicago Press, Chicago, IL.

Belotti F., Daidone S., Ilardi G. (2012) Stochastic Frontier Analysis Using Stata, Stata Journal, 13, 719-758.

Byrnes J., Miller D., Schafer W. (1999) Gender Differences in Risk Taking: A MetaAnalysis, Psychological Bulletin, LXXXV, 367-383.

Campbell K., Minguez-Vera A. (2008) Gender Diversity in the Boardroom and Firm Financial Performance, Journal of Business Ethics, 83, 435-451.

Carli L.J. (1990) Gender, Language, and Influence, Journal of Personality and Social Psychology, 59, 5, 941-52.

Carter D., Simkins B., Simpsons W. (2003) Corporate Governance, Board Diversity, and Firm Value, Financial Review, 38, 1, 33-53.

Carter D., D'Souza F., Simkins B., Simpsons W. (2010) The Gender and Ethnic Diversity of US Boards and Board Committees and Firm Financial Performance, Corporate Governance, 18, 5, 396-414.

Daunfeldt S.-O., Rudholm N. (2012) Does Gender Diversity in the Boardroom Improve Firm Performance?, Working Paper, HUI Research.

Davidson R., MacKinnon J. (2004) Econometric Theory and Methods, New York: Oxford University Press.

Demsetz H., Villalonga B. (2001) Ownership Structure and Corporate Performance, Journal of Corporate Finance, 7, 3, 209-233

Demsetz H., Lehn K. (1985) The Structure of Corporate Ownership: Causes and Consequences, Journal of Political Economy, 93, 6, 1155-1177.

Eckel C., Grossman P. (2002) Sex Differences and Statistical Stereotyping in Attitudes Toward Financial Risks, Evolution and Human Behavior, 23, 4, 281295.

Eckel C., Grossman P. (2008) Men, Women and Risk Aversion: Experimental Evidence, Handbook of Experimental Economics Results, 1, chap.113, 10611073.

Erhardt N.L., Werbel J.D., Shrader C.B. (2003) Board of Director Diversity and Firm Financial Performance, Corporate Governance: An International Perspective, 11, 2, 102-111.

Farrell M.-J. (1957) The Measurement of Productive Efficiency, Journal of the Royal Statistical Society, 120, 230-253.

Farrell K.A., Hersch P.L. (2005) Additions to Corporate Boards: The Effect of Gender, Journal of Corporate Finance, 11, 1/2, 85-106.

Ferrary M. (2009) Les Femmes: Un Remède à la Crise Boursière?, Ressources Humaines \& Management, 28, 3-6. 
Ferrary M. (2010) Les Femmes Influencent-elles la Performance des Entreprises?, Travail, Genre et Sociétés, 23, 181-191.

Hartaeska V., Nadolnyak D. (2012) Board Size and Diversity as Governance Mechanisms in Community Development Loan Funds in the USA, Applied Economics, 33, 4313-4329.

Hausman, J.A., Taylor W.E. (1981) Panel data and unobservable individual effects, Econometrica, 49, 1377-1398.

Hermalin B., Weisbach M. (2003) Boards of Directors as an Endogenously Determined Institution: A Survey of the Economic Literature Federal Bank of New-York Economic Policy Review, 9, 1, 7-26.

Hillman A.J., Cannella A.A., Paetzold R. (2000) The Resource Dependence Role of Corporate Directors: Adaptation of Board Composition in Response to Environmental Change, Journal of Management Studies, 37, 2, 235-255.

Hillman A.J., Sphropshire C., Cannella A.A. (2007) Organizational Predictors of Women on Corporate Boards, Academy of Management Journal, 50, 2, 941952.

Huang C.J., Liu J-T. (1994) Estimation of a Non-Neutral Stochastic Frontier Production Function, Journal of Productivity Analysis, 5, 171-180

Huse M., Solberg A.G. (2006) Gender-Related Boardroom Dynamics: How Scandinavian Women Make and Can Make Contributions on Corporate Boards, Women in Management Review, 21, 2, 113-30.

Kanter R. (1977) Some Effects of Proportions on Group Life: Skewed Sex Ratios and Responses to Token Women, The American Journal of Sociology, 82, 5, 965 990.

Kini O., Kracaw W., Mian S. (1995) Corporate Takeovers, Firm Performance and Board Composition, Journal of Corporate Finance, 1, 383-412.

Konrad A.M., Kramer V., Erkut S. (2008) Critical Mass: The Impact of Three or More Women on Corporate Boards, Organizational Dynamics, 37, 2, 145-64.

Kumar Mishra R., Jhunjhunwala S. (2013) Diversity and the Effective Corporate Board, Academic Press.

Kumbhakar S.C., Ghosh S., McGuckin J.T (1991) A Generalized Production Frontier Approach for Estimating Determinants of Inefficiency in U.S. Dairy Farms, Journal of Business and Economic Statistics, 9, 279-286.

Landrieux-Kartochian S. (2004) La Contribution des Femmes à la Performance: Une Revue de la Littérature, Document d'Etudes DARES, 83.

Moulin Y., Point S. (2012) Les Femmes dans les Conseils d'Administration du SBF120: Qualités Féminines ou Affaires de Famille?, Gestion des Ressources Humaines, 83, 31-44

Peterson C.A., Philpot J. (2007) Women's Roles on US Fortune 500 Boards: Director Expertise and Committee Membership, Journal of Business Ethics, 72, 177-96.

Rose C. (2007) Does Female Board Representation Influence Firm Performance? The Danish Evidence, Corporate Governance, 15, 1, 404-413.

Ross-Smith A., Bridge J. (2008) 'Glacial at Best': Women's Progress on Corporate Boards in Australia", in Women on Corporate Boards of Directors, Edited by S. Vinnicombe, V. Singh, R.J. Burke, D. Bilimoria et M. Huse, 6.

Saint-Onge S., M. Magnan (2013) Les Femmes au Sein des Conseils d'Administration: Bilan des Connaissances et Voies de Recherche Futures, Finance, Contrôle et Stratégie, 16, 1, 2-21. 
Sealy R., Singh V., Vinnicombe S. (2007) The Female FTSE Report 2007, Cranfield, UK.

Singh V., Terjesen S., Vinnicombe S. (2008) Newly Appointed Directors in the Boardroom: How do Women and Men Differ?, European Management Journal, 26, 1, 48-58.

Terjesen, S. Sealy, R., Singh V. (2009) Women Directors on Corporate Boards: A Review and Research Agenda, Corporate Governance: An International Review, 17, 320-337.

Zelechowski D., Bilimoria D. (2004) Characteristics of Women and Men Corporate inside Directors in the US, Corporate Governance: An International Review, 12, 3, 337-42. 


\section{Appendix}

Table A1. Gender diversity and performance (random effect model)

\begin{tabular}{|c|c|c|}
\hline & \\
\hline & ROA & Tobin's $q$ \\
\hline Fraction of Women & $\begin{array}{l}0.407 * * \\
(2.092)\end{array}$ & $\begin{array}{l}0.324 * * \\
(1.978)\end{array}$ \\
\hline High independent firm & $\begin{array}{l}0.907 * \\
(1.944)\end{array}$ & $\begin{array}{l}0.044 * \\
(1.907)\end{array}$ \\
\hline Family-controlled firm & $\begin{array}{l}0.321 * \\
(1.940)\end{array}$ & $\begin{array}{l}0.056 * * \\
(1.973)\end{array}$ \\
\hline Independent firm $\mathrm{x}$ family control firm & $\begin{array}{l}0.004 * \\
(1.945)\end{array}$ & $\begin{array}{l}0.003 * \\
(1.834)\end{array}$ \\
\hline Firm size (in logarithms) & $\begin{array}{l}2.106 * * * \\
(2.902)\end{array}$ & $\begin{array}{l}2.481 * * * \\
(2.946)\end{array}$ \\
\hline Business segment: service & $\begin{array}{l}-0.623 \\
(-0.904)\end{array}$ & $\begin{array}{l}-0.657 \\
(-1.329)\end{array}$ \\
\hline Date of firm's creation & $\begin{array}{l}-0.002 \\
(-0.561)\end{array}$ & $\begin{array}{l}-0.003 \\
(-0.129)\end{array}$ \\
\hline Number of directors in boards & $\begin{array}{l}-0.046 \\
(-0.388)\end{array}$ & $\begin{array}{l}-0.041 \\
(-0.921)\end{array}$ \\
\hline$R O A$ in $t-1$ & $\begin{array}{l}0.186^{* *} \\
(2.089)\end{array}$ & \\
\hline Tobin's $q$ in $t-1$ & & $\begin{array}{l}0.779 * * * \\
(2.978)\end{array}$ \\
\hline Constant & $\begin{array}{l}16.467 \\
(1.212)\end{array}$ & $\begin{array}{l}0.812 \\
(1.003)\end{array}$ \\
\hline $\mathrm{R}^{2}$ (total) & 0.497 & 0.563 \\
\hline Number of observations & 160 & 160 \\
\hline Number of firms & 40 & 40 \\
\hline
\end{tabular}

Notes: Student's $t$ values are in brackets.

$* * *$ Significant at $1 \%$. $* *$ Significant at $5 \%$. $*$ Significant at $10 \%$. 
Table A2: Gender diversity and performance (frontier model)

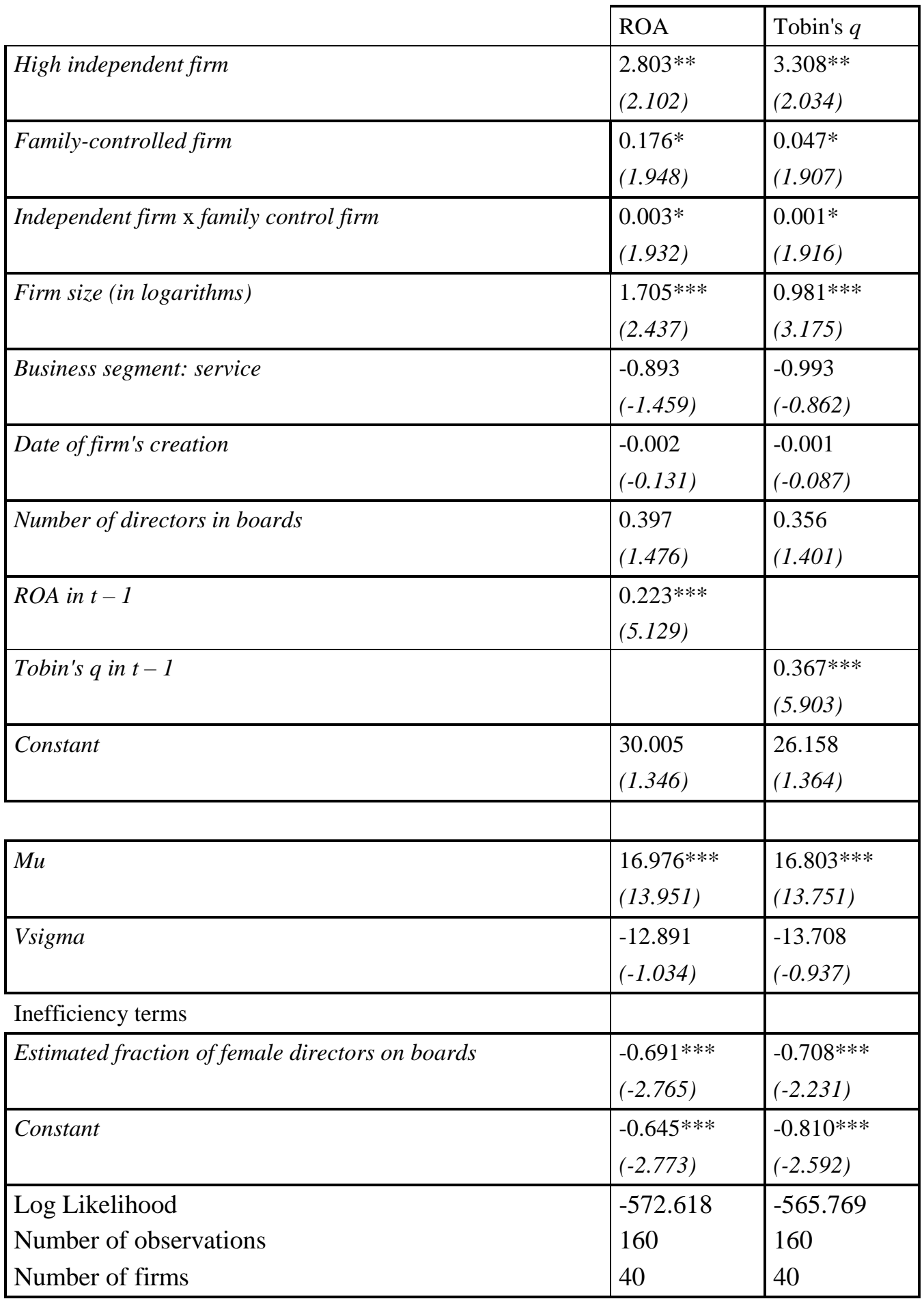

Notes: Student's $t$ values are in brackets.

$* * *$ Significant at $1 \%$. $* *$ Significant at $5 \%$. $*$ Significant at $10 \%$. 